\title{
Malignant peripheral nerve sheath tumour of the renal parenchyma presenting as a fast growing atypical renal cyst
}

\author{
Simon Ouellet, MD; ${ }^{*}$ Alexandre Doueik, MD; ${ }^{\dagger}$ Robert Sabbagh, MSc, MD, FRCSC ${ }^{*}$
}

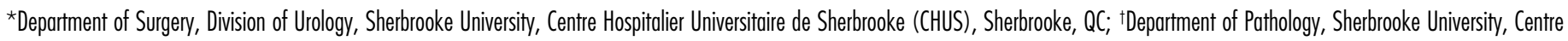
Hospitalier Universitaire de Sherbrooke (CHUS), Sherbrooke, QC

Cite as: Can Urol Assoc J 2013;7(9-10):e601-4. http://dx.doi.org/10.5489/cuaj.411 Published online September 10, 2013.

\section{Abstract}

Malignant peripheral nerve sheath tumours (MPNST) of the kidney are very rare, with only 3 cases reported in the English and French literature. However, we report the first case of fast growing atypical renal cyst where a magnetic resonance imaging was an interesting adjunct to the computed tomography scan in imaging this rare tumour.

\section{Introduction}

Malignant peripheral nerve sheath tumours (MPNST), also known as malignant schwannoma, arise from Schwann cells which are derived from the neural crest. These tumours are often associated with Von Recklinghausen's disease. ${ }^{1-3}$ Preoperative diagnosis remains challenging and is based on histology and positive immunohistochemical studies for S-100 protein. Occurrence is usually in the head and neck region or in the limbs. ${ }^{2-5}$ Renal or perirenal MPNST are exceptionally rare findings. We report a case of renal malignant peripheral nerve sheath tumour that highlights the importance of a magnetic resonance imaging (MRI) in such situation.

\section{Case report}

A 70-year-old ex-smoking male known for hypertension, diabetes mellitus, dyslipidemia, obesity (body mass index 40) and chronic renal failure (estimated glomerular filtration rate $45.4 \mathrm{~mL} / \mathrm{min} / 1.73 \mathrm{~m}^{2}$ ) was referred to our institution for a growing renal cyst. The patient was asymptomatic and physical examination was unremarkable. Personal and familial history was negative for von Recklinghausen's disease. Laboratory studies, including complete blood count, electro-
Iytes, urinalysis, glycemia and hepatic profile, were normal except for a high level of serum creatinine and normocytic anemia secondary to chronic renal disease. A computed tomography (CT) scan confirmed multiple simple cysts on both kidneys, except for an 8-cm left mid-upper pole dense cyst. A controlled CT scan 6 months later showed a slight growth and peripheral rim enhancement of this cyst with subtle changes in its content (Fig. 1, part A). An ultrasound confirmed some internal echoes compatible with cellular content. A MRI was recommended by our radiologist 2 months later, and showed a slightly hypointense left renal lesion (Fig. 1, part B) with heterogeneous enhancement following gadolinium administration on $\mathrm{T}_{1}$-weighted images (Fig. 1, part C). Lesion also appeared heterogeneously hyperintense on $\mathrm{T}_{2}$-weighted images. (Fig. 1, part D). Considering the differences between the CT and the MRI images, our radiologist suggested a repeat abdominal CT scan 3 months later which showed significant growth of the left renal mass to $14 \mathrm{~cm}$ with heterogeneous internal enhancement (Fig. 1, part E) suggesting a renal tumour. There was focal fat stranding involving the perirenal space. The renal vein remained permeable and without hydronephrosis.

The patient underwent a transperitoneal laparoscopic radical nephrectomy. Lymph nodes were explored during surgery and none were found. Ipsilateral adrenal gland was not removed because it was radiologically normal.

Gross examination of the specimen showed a $17 \times 14 \times 10-\mathrm{cm}$ kidney weighting about $3 \mathrm{~kg}$. The tumour was gray-white, $15 \mathrm{~cm}$ in length and occupied almost all renal parenchyma (Fig. 2). Macroscopically, the tumour infiltrated perirenal fat and was in proximity to the fascia of Gerota without reaching it.

Histological examination (Fig. 3, part A) revealed a sarcoma with fusiform cell. Mitotic count showed multiple zones with $>10$ mitosis per high field power. Multiple areas of tumour necrosis were found. Adjacent renal parenchyma was normal, except for glomerular hyperfiltration related to chronic renal failure. No vascular emboli were present 


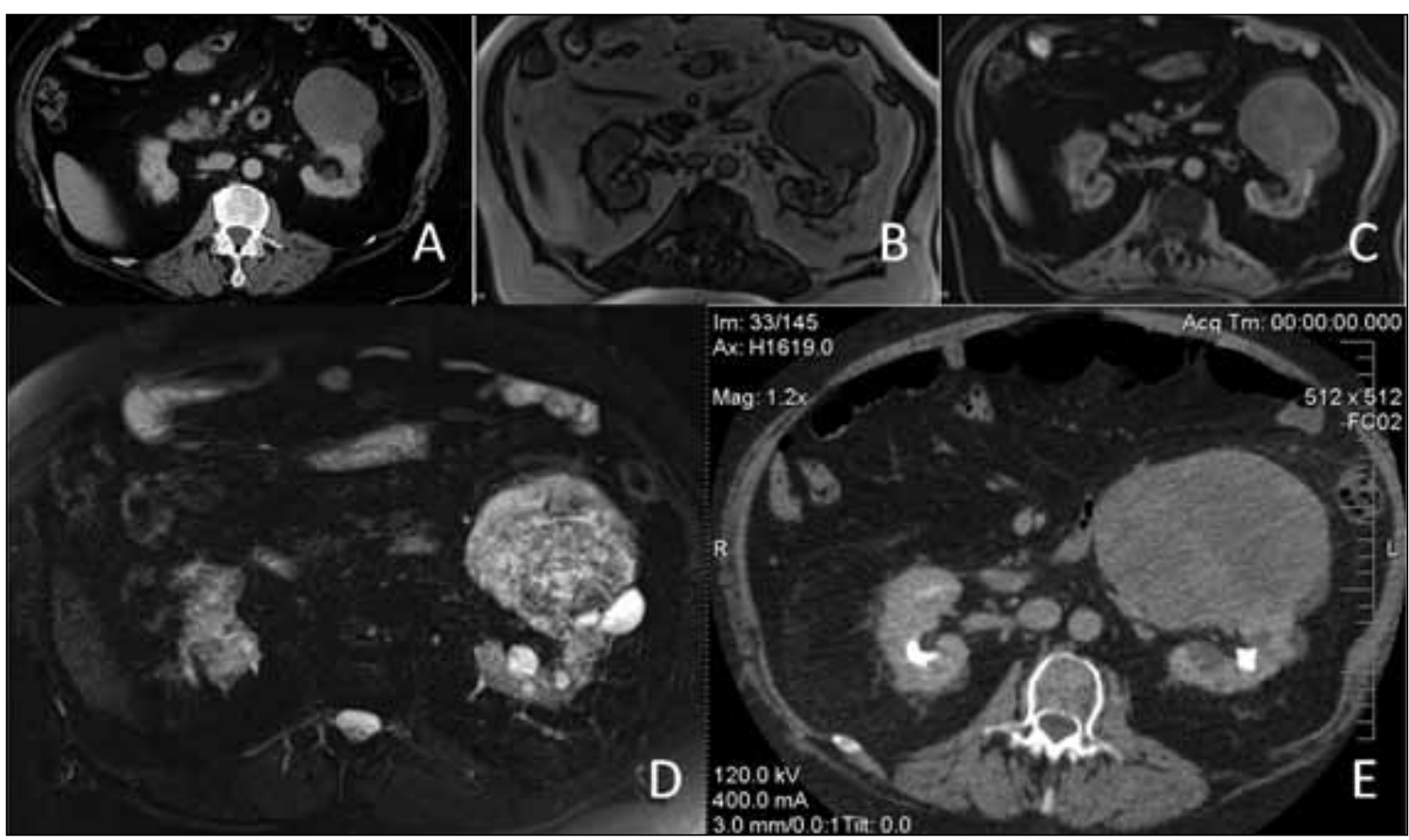

Fig. 1. (A) Contrast enhanced computed tomography (CT) scan shows a 8-cm left renal lesion with a density of 13 Hounsfield units and slight peripheral rim enhancement. (B) $T_{1}$-weighted magnetic resonance image reveals a slightly hypointense left renal lesion (C) which shows peripheral and heterogeneous internal enhancement following gadolinium administration. (D) $0 n T_{2}$-weighted image, the left renal lesion appears heterogeneously hyperintense, with a small and very hyperintense (cystic) posterior component. (E) There is a significant growth to $14 \mathrm{~cm}$ of the left renal lesion on a follow-up contrast enhanced CT scan done 3 months later. The lesion shows heterogeneous internal enhancement and displaces the kidney posteriorly.

and surgical margins were negative. Immunohistochemical studies of the tumour showed strong S-100 immunoreactivity (Fig. 3, part B) consistent with MPNST and $40 \%$ to $50 \%$ of tumour cells were positive for Ki-67 (Fig. 3, part C).

Six months after surgery, the CT scan revealed a $7-\mathrm{cm}$ ipsilateral renal fossa tumour recurrence, as well as a metas-

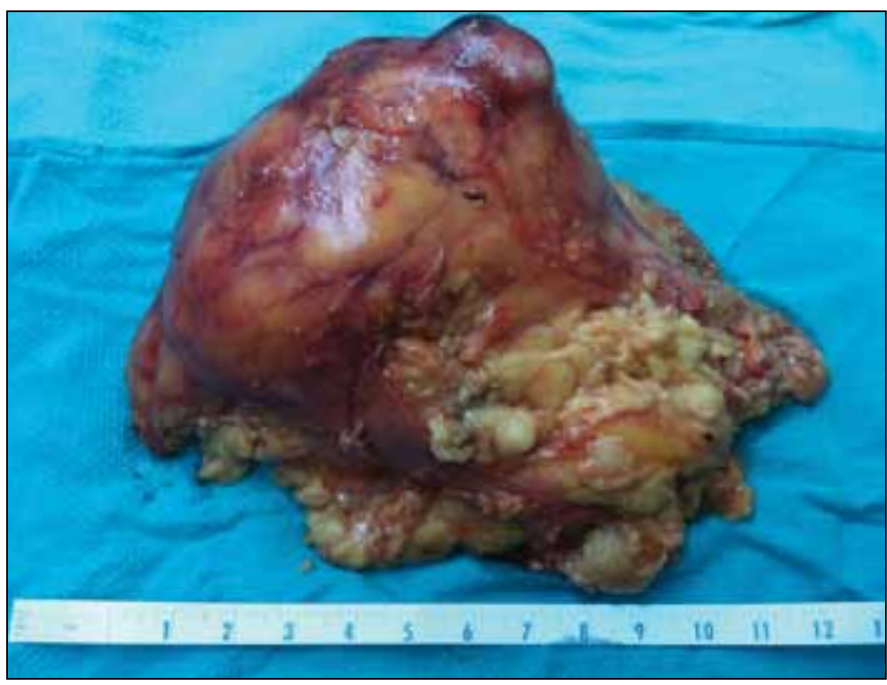

Fig. 2. Gross pathology specimen removed by a transperitoneal laparoscopic approach. Ruler graduated in inches. tasis to the ipsilateral adrenal and pancreas. The patient died 10 months after his surgical procedure.

\section{Discussion}

MPNST are exceptionally rare tumours with an incidence of 1 to 10 per 1000000 , representing between $3 \%$ and $12 \%$ of all soft tissue sarcomas. ${ }^{1,2}$ These tumours are usually found in patients between 20 to 50 years old, in the head and neck region, trunk or in the limbs. ${ }^{2-5}$ MPNST show poor prognosis, with reported rates of 5-year disease specific survival of $16 \%$ to $60 \% .^{1-5}$ The most effective treatment remains surgical resection and margin status is of primary importance. . $^{2-4,6}$ Conflicting evidence suggests that adjuvant radiotherapy might play a role in the management of MPNST ${ }^{1-3,6}$ However, no studies found that chemotherapy improves survival. ${ }^{1-3,5,7}$

We report the fourth case of MPNST in the renal parenchyma (Table 1). ${ }^{8-10}$ Martinot and colleagues ${ }^{8}$ reported the first case in 1960 of a 70-year-old male whose left kidney was almost totally replaced by tumour tissue; this patient died on postoperative day 5 . Naslund and colleagues ${ }^{9}$ described an aggressive case of MPNST invading the diaphragm and lung. Surgical margins were positive and the patient declined radiation and chemotherapy. Four months later a $7-\mathrm{cm}$ lesion was found in the renal fossa and the patient eventually died 15 months after surgery. Most recent- 


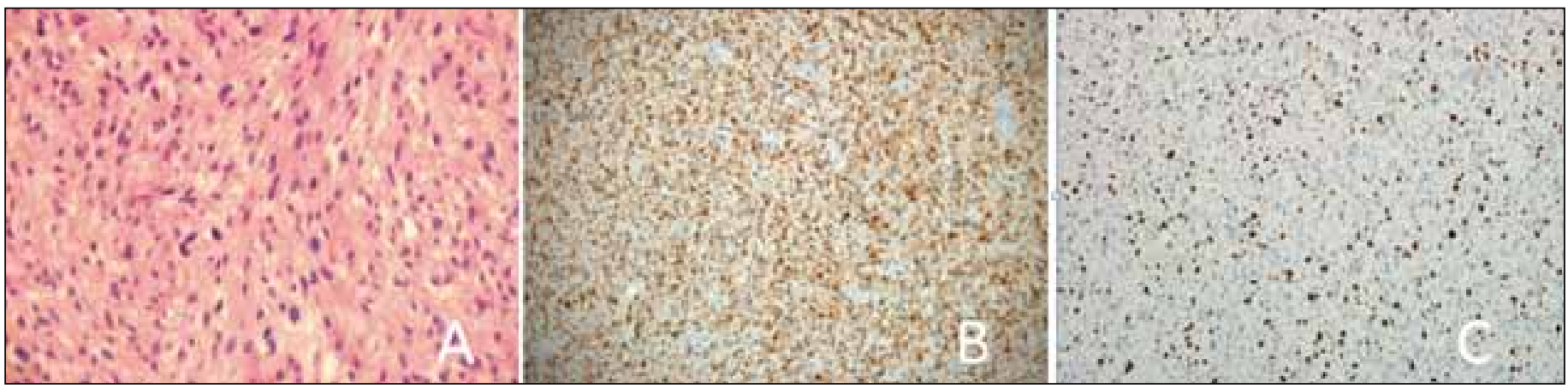

Fig. 3. (A) Microscopic imaging (hematoxylin and eosin stain; 40x) of the tumoural proliferation composed of spindle cells with moderate cellularity and nuclear atypia (B) Immunohistochemical study demonstrating strong S-100 immunoreactivity consistent with the diagnosis of malignant peripheral nerve sheath tumours.

(C) $40 \%$ to $50 \%$ of the tumour cells were positive for Ki-67. Tumour cells were negative for muscle markers.

Iy, a case of renal MPNST with metastasis to the scalp, lung and shoulder was treated with neoadjuvant doxorubicin and surgical resection of all lesions. ${ }^{10}$ This patient is free from recurrence at the 2-year follow-up.

Cases of MPNST of the renal capsule were also reported. ${ }^{11-13}$ Romics and colleagues ${ }^{13}$ reported a case of MPSNT arising from the right renal capsule invading liver and extending up to diaphragm. Surgical margins were positive and the patient developed pulmonary metastasis and died at 3 months following surgical resection. Longer sur- vivals of $24^{14}$ and $36^{15}$ months were reported in 2 cases of renal pelvis MPSNT. Primary ${ }^{16-19}$ and metastatic ${ }^{20,21}$ perirenal MPNST have also been reported and tend to present as large renal masses.

Despite the fact that most MPNST are diagnosed in patients with von Recklinghausen's disease, ${ }^{1-3}$ no renal or perirenal cases were reported. The diagnosis of renal or perirenal MPNST remains challenging and was established by pathologic examination in all reported cases. As known, the renal CT scan is the gold standard for delineating the

\begin{tabular}{|c|c|c|c|c|c|}
\hline First author & Age/ Sex & Presentation & Size/side, site $(\mathrm{cm})$ & Main treatment & Follow-up \\
\hline Present case & 70/M & Incidental finding & 15/left, parenchyma & $\begin{array}{l}\text { Laparoscopic radical } \\
\text { nephrectomy }\end{array}$ & Died at $10 \mathrm{mo}$ \\
\hline Martinot $^{8}$ & 70/M & $\begin{array}{l}\text { Lower back and flank pain, } \\
\text { weight loss, fatigue, fever }\end{array}$ & NR/left, parenchyma & Radical nephrectomy & $\begin{array}{l}\text { Died } 5 \text { days } \\
\text { postoperative }\end{array}$ \\
\hline Naslund ${ }^{9}$ & $50 / F$ & $\begin{array}{c}\text { Flank pain, weight loss, } \\
\text { palpable mass }\end{array}$ & 14/left, parenchyma & Radical nephrectomy & $\begin{array}{l}\text { Died at } 15 \text { mo with } \\
\text { metastasis }\end{array}$ \\
\hline Williams $^{10}$ & $75 / F$ & Scalp lesion (metastasis) & 8/left, parenchyma & Radical nephrectomy & $24 \mathrm{mo}$ \\
\hline Khandelwal ${ }^{11}$ & 40/M & $\begin{array}{l}\text { Lower back discomfort, } \\
\text { palpable mass }\end{array}$ & NR/left, renal capsule & Radical nephrectomy & NR \\
\hline Jankulovski ${ }^{12}$ & $65 / F$ & $\begin{array}{l}\text { Flank pain, weight loss, } \\
\text { palpable mass }\end{array}$ & 13/left, renal capsule & Radical nephrectomy & $6 \mathrm{mo}$ \\
\hline Romics $^{13}$ & $52 / \mathrm{M}$ & Flank pain, fever & $\begin{array}{l}\text { NR/right, renal } \\
\text { capsule }\end{array}$ & Radical nephrectomy & $\begin{array}{l}\text { Died at } 3 \text { mo with } \\
\text { metastasis }\end{array}$ \\
\hline Voznesensky $^{15}$ & $46 / F$ & Gross hematuria & 4/right, renal pelvis & $\begin{array}{c}\text { Laparoscopic } \\
\text { nephroureterectomy }\end{array}$ & $36 \mathrm{mo}$ \\
\hline Fein $^{14}$ & $51 / F$ & $\begin{array}{c}\text { Flank pain, recurrent } \\
\text { pyelonephritis, palpable mass }\end{array}$ & $6 /$ right, renal pelvis & Radical nephrectomy & $24 \mathrm{mo}$ \\
\hline Pantuck $^{16}$ & $50 / F$ & Palpable mass & 28/right, perirenal & Radical nephrectomy & Died at $42 \mathrm{mo}$ \\
\hline Parfitt ${ }^{17}$ & $63 / \mathrm{M}$ & $\begin{array}{l}\text { Weakness, fatigue, weight loss, } \\
\text { palpable mass }\end{array}$ & $\begin{array}{l}11 \text { and } 6 / \text { left, } \\
\text { perirenal }\end{array}$ & Radical nephrectomy & $9 \mathrm{mo}$ \\
\hline Bair ${ }^{18}$ & $56 / \mathrm{M}$ & Microscopic hematuria & 7/right, perirenal & Radical nephrectomy & $5 \mathrm{mo}$ \\
\hline Deming $^{19}$ & $33 / \mathrm{F}$ & Abdominal pain, palpable mass & NR/left, perirenal & $\begin{array}{c}\text { Tumour excision without } \\
\text { nephrectomy }\end{array}$ & $\begin{array}{l}\text { Died at } 11 \text { mo with } \\
\text { metastasis }\end{array}$ \\
\hline Cachay $^{20}$ & $74 / F$ & $\begin{array}{c}\text { Follow-up for malignant } \\
\text { subcutaneous schwannoma }\end{array}$ & 9/right, metastasis & Radical nephrectomy & $5 \mathrm{mo}$ \\
\hline $\begin{array}{l}\text { García } \\
\text { Figueiras }^{21}\end{array}$ & $73 / F$ & $\begin{array}{l}\text { Follow-up for malignant } \\
\text { soft-tissue MPNST }\end{array}$ & $8 /$ right, metastasis & Radical nephrectomy & Died at $5 \mathrm{mo}$ \\
\hline
\end{tabular}


nature of a renal mass and MRI remains an alternate modality. However, some MRI findings were reported to be suggestive of benign peripheral nerve sheath tumour (PNST). ${ }^{22}$ They included isointensity on $\mathrm{T}_{1}$-weighted images, a high signal intensity on $\mathrm{T}_{2}$-weighted images ${ }^{22,23}$ and strong and homogeneous gadolinium-enhancement on $\mathrm{T}_{1}$-weighted images. $^{24,25}$ We report, however, the first case of malignant tumor with MRI. Although our case had heterogeneous enhancement following gadolinium administration, it shared some features of PNST, such as enhancing outer rim on $\mathrm{T}_{1}$-weighted images and hyperintensity on $\mathrm{T}_{2}$-weighted images, $^{22,23}$ that should raise suspicion for MPNST. Finally, the rapid evolution of the radiological features reported in this case and the poor survival shows the aggressiveness of MPNST.

In this case, the discrepancies between $\mathrm{CT}$ scan and MRI images might be due to the superiority of MRI for detecting such tumours or to actual tumour growth as images were taken 2 months apart. However, it shows that MRI might help in the differential diagnosis of renal cyst when ultrasonography and CT scan cannot provide a definitive diagnosis. It also highlights the importance of MRI and serial radiological follow-up for atypical renal cyst with rapid growth that might carry poor prognosis and should prompt surgical management.

\section{Conclusion}

We reported a rare case of MPNST presenting as an atypical renal cyst where MRI provided important information along with the CT scan.

Acknowledgements: We would like to thank Tania Fayad, PhD, for the critical reading of this article.

Competing interests: None declared.

This paper has been peer-reviewed.

\section{References}

1. Kar M, Deo SV, Shukla NK, et al. Malignant peripheral nerve sheath tumors (MPNST) - Clinicopathological study and treatment outcome of twenty-four Cases. World I Surg Oncol 2006;4:55. http://dx.doi. org/10.1186/1477-7819-4-55

2. Ducatman BS, Scheithauer BW, Piepgras DG, et al. Malignant peripheral nerve sheath tumors. A clinicopathologic study of 120 cases. Cancer 1986;57:2006-21. http://dx.doi.org/10.1002/10970142(19860515)57:10<2006::AID-CNCR2820571022>3.0.C0;2-6
3. Wanebo JE, Malik JM, VandenBerg SR, et al. Malignant peripheral nerve sheath tumors. A clinicopathologic study of 28 cases. Cancer 1993;71:1247-53. http://dx.doi.org/10.1002/10970142(19930215)71:4<1247::AID-CNCR2820710413>3.0.C0;2-S

4. Lafemina J, Qin LX, Moraco NH, et al. Oncologic outcomes of sporadic, neurofibromatosis-associated, and radiation-induced malignant peripheral nerve sheath tumors. Ann Surg Oncol 2013;20:66-72. http:// dx.doi.org/10.1245/s10434-012-2573-2. Epub 2012 Aug 10.

5. Stucky CC, Johnson KN, Gray RJ, et al. Malignant peripheral nerve sheath tumors (MPNST): the Mayo Clinic experience. Ann Surg Oncol 2012;19:878-85. http://dx.doi.org/10.1245/s10434-011-1978-7

6. Anghileri $M$, Miceli $R$, Fiore $M$, et al. Malignant peripheral nerve sheath tumors: prognostic factors and survival in a series of patients treated at a single institution. Cancer 2006;107:1065-74. http://dx.doi. org/10.1002/cncr.22098

7. Moretti VM, Crawford EA, Staddon AP et al. Early outcomes for malignant peripheral nerve sheath tumor treated with chemotherapy. Am J Clin Oncol 2011;34:417-21. http://dx.doi.org/10.1097/ COC.0b013e3181e9c08a

8. Martinot M, Dupont A, Demaille A. Malignant schwannoma of the kidney. J Urol Medicale Chir 1960;66:748-52.

9. Naslund MJ, Dement S, Marshall FF. Malignant renal schwannoma. Urology 1991;38:477-9. http:// dx.doi.org/10.1016/0090-4295(91)80243-Z

10. Williams SB, Szlyk GR, Manyak MJ. Malignant peripheral nerve sheath tumor of the kidney. Int I Urol 2006;13:74-5. http://dx.doi.org/10.1111/i.1442-2042.2006.01238.x

11. Khandelwal A, Gupta A, Khandelwal K. Malignant peripheral nerve sheath tumor of the kidney. Iran J Kidney Dis 2011;5:373.

12. Jankulovski N, Stankov 0 , Banev $S$, et al. Isolated malignant peripheral nerve sheath tumor of kidney capsule. Prilozi 2008;29:361-9.

13. Romics I, Bach D, Beutler W. Malignant schwannoma of kidney capsule. Urology 1992;40:453-5. http:// dx.doi.org/10.1016/0090-4295(92)90463-7

14. Fein RL, Hamm FC. Malignant schwannoma of the renal pelvis: a review of the literature and a case report. J Urol 1965;94:356-61.

15. Voznesensky MA, Yamase H, Taylor JA. Malignant peripheral nerve sheath tumor of the renal pelvis. Urol Int 2009;83:370-2. http://dx.doi.org/10.1159/000241687

16. Pantuck AJ, Barone JG, Amenta PS, et al. Diagnosis and management of malignant perirenal schwannoma. Am Surg 1996;62:1024-7.

17. Parfitt HE Jr, Hammond ME, Middletin AW Jr. Perirenal malignant schwannoma: a case report and review of the literature. J Urol 1982;128:1299-301.

18. Bair ED, Woodside JR, Williams WL, et al. Perirenal malignant schwannoma presenting as renal cell carcinoma. Urology 1978; 11:510-2. http://dx.doi.org/10.1016/0090-4295(78)90173-5

19. Deming CL, Newman HR. Schwannomas. J Urol 1954;72:316-23.

20. Cachay M, Sousa-Escandón A, Gibernau R, et al. Malignant metastatic perirenal schwannoma. Scand J Urol Nephrol 2003;37:443-5. http://dx.doi.org/10.1080/00365590310019026

21. García Figueiras R, Cachay Ayala ME, et al. Solitary perirenal metastasis from a malignant peripheral nerve sheath tumour mimicking a primary renal tumour. Australas Radiol 2003;47:188-9. http://dx.doi. org/10.1046/i.0004-8461.2003.01150.x

22. Hung SF, Chung SD, Lai MK, et al. Renal schwannoma: case report and literature review. Urology 2008;72:716e3-6. http://dx.doi.org/10.1016/j.urology.2007.12.056

23. Singer AJ, Anders KH. Neurilemoma of the kidney. Urology 1996;47:575-81. http://dx.doi. org/10.1016/S0090-4295(99)80500-7

24. Tsurusaki M, Mimura F, Yasui N, et al. Neurilemoma of the renal capsule: MR imaging and pathologic correlation. Eur Radiol 2011;11:1824-37.

25. Kitagawa K, Yamahana T, Hirano $S$, et al. MR imaging of neurilemoma arising from the renal hilus. J Comput Assist Tomogr 1990;14:830-2. http://dx.doi.org/10.1097/00004728-199009000-00034

Correspondence: Dr. Robert Sabbagh, Department of Surgery, Division of Urology, Sherbrooke University, Centre Hospitalier Universitaire de Sherbrooke (CHUS), 3001, 12 Avenue Nord, Sherbrooke, Quebec, JIH 5N4; fax: 819-820-6411; robert.sabbagh@usherbrooke.ca 